\title{
The Effectiveness of intervention based on positive education on the subjective wellbeing in students
}

\author{
Ali Taghvaeinia ${ }^{1}$ \\ 1-Assistant Professor, Department of Psychology, Yasouj University, Yasouj, Iran (Corresponding Author). \\ ORCID: 0000-0002-6655-3420 \\ E-mail:taghvaei.ali2@g mail.com
}

Received: 04/11/2018

Accepted: 12/01/2019

\section{Abstract}

Introduction: Subjective wellbeing is one of important constructs of the positive psychology and identifying the factor affecting it is of paramount importance and promotion of subjective well-being is one of the objectives of the modern psychology.

Aim: This study examined the effectiveness of the intervention based on positive education on subjective wellbeing in students.

Method: Research design was semi-experimental and pretest- posttest type with the control group. The study population included all the male $6^{\text {th }}$ grade students in Marvdasht, Iran. From among these students, 30 were selected through cluster sampling as the samples of the research. For the collecting the data Positive Affect and Negative Affect Schedule (PANAS), and Satisfaction With Life Scale (SWLS) were used. For the data analysis, multivariate analysis of covariance was used.

Results: The results showed that the intervention positive education enhanced positive affection and life satisfaction and reduced negative affection in the expremental group in comparison with the control group.

Conclusion: The findings of this research has practiced implication to pay special attention the effects of intervention positive education on students' subjective wellbeing.

KeyWords: Intervention based on positive education, Subjective wellbeing, Students

How to cite this article :Taghvaeinia A. The Effectiveness of intervention based on positive education on the subjective wellbeing in students. Shenakht Journal of Psychology and Psychiatry. 2019; 6 (1): 125-137.URL :http://shenakht.muk.ac.ir/article-1-614-fa.pdf

Copyright (c) 2018 the Author (s). Published by Kurdistan University of Medical Sciences. This is an open access article distributed under the terms of the Creative Commons Attribution-Non Commercial License 4.0 (CCBY-NC), where it is permissible to download, share, remix, transform, and buildup the work provided it is properly cited. The work cannot be used commercially without permission from the journal. 


\section{اثربخشى مداخلهى مبتنى بر آموزش مثبت بر بهزيستى ذهنى دانش آموزان}

\section{على تقوائى نيا'}

taghvaei.ali2@g mail.com :استاديار، گروه روانشناسى، دانشگاه ياسوج، ياسوج، ايران (مولف مسئول). ايميل

تاريخ دريافت مقاله:

جָكيله

مقدمه: بهزيستى ذهنى يكى از سازههاى مهم روانشناسى مثبت گرا است كه شناسايى عوامل مؤثر در آن از اهميت زيادى برخوردار

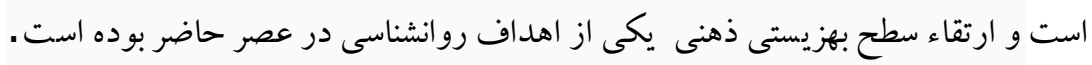
هدف: يُزوهش حاضر با هدف اثربخشى مداخلهى مبتى بر آموزش مثبت بر بهزيستى ذهنى دانش آموزان انجام كرفت.

روش: طرح يزوهش، نيمه تجربى و از نوع ييش آزمون - يس آزمون و گروه كنترل بود. جامعه آمارى يزوهش را كليه دانش آموزان

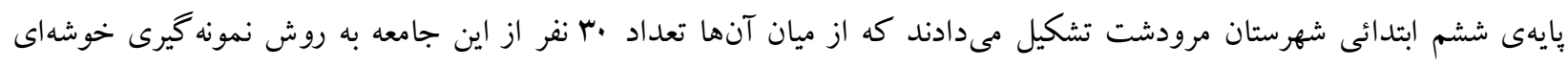

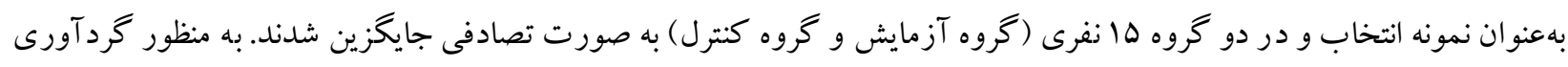

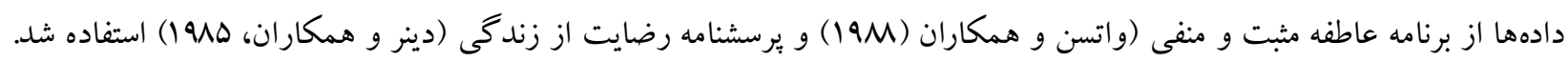
براى تجزيه و تحليل دادهها، از آزمون تحليل كواريانس جندمتغيرى استفاده شد.

يافتهها: نتايج نشان داد مداخله آموزش مثبت موجب ارتقاء عاطفه مثبت و رضايت از زندگى و كاهش عاطفه منفى گروه آزمايش در مقايسه با گروه كنترل گر ديد.

نتيجه كيرى: يافته هاى اين بثوهش تلويحات كاربردى مهمى جهت اهتمام ويزه به تأثير مداخله آموزش مثبت در بهزيستى ذهنى دانش آموزان دارد. كليد وازهها: مداخلهى مبتى بر آموزش مثبت، بهزيستى ذهنى، دانش آموزان 
قابلملاحظهاى برخوردار هست (كنز الز 'لو همكاران،

مقدمه

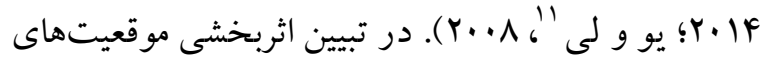
تحصيلى، بزوهش هاى انجامشده بر يكى از دو رويكرد

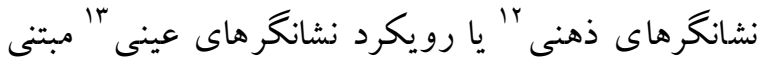
بودهاند. در رويكرد نشانگرهاى عينى، اثربخشى يك دونى محيط تحصيلى از طريق تأكيد بر عوامل كمّى، از قبيل نمرههاى بيشرفت تحصيلى يادكيرندگان و در رويكرد نشانكرهاى ذهنى، اثربخشى محيطهاى تحصيلى، از طر يق

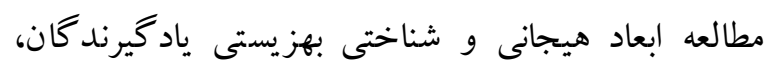
تعيين مىشود. بنابراين، رويكرد نشانگر هاى ذهنى، بيانگر

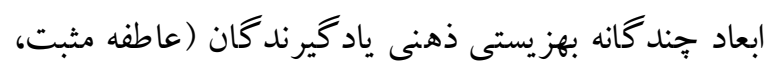
عاطفه منفى و رضايت از زندگى) است (كاراتزس، ياور،

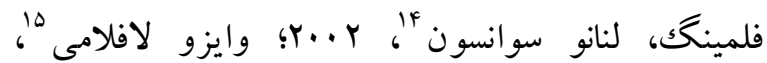

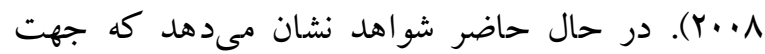
افزايش عاطفه مثبت، كاهش عاطفه منفى و بهبود رضايت از زندكى دانش آموزان مى توان با استفاده از مداخلات متمر كز بر روانشناسى مثبت نخر در ارتقاء بهز يستى ذهنى

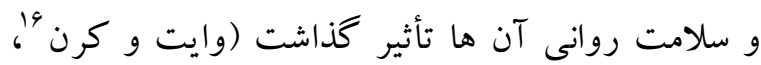
1

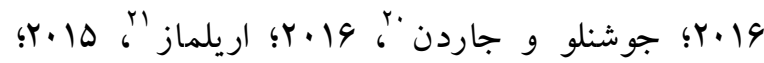

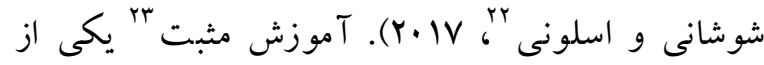
اشكال متنوع روانشناسى مثبت است كه هدف آن آماج قرار دادن عواطف ناخوشايند، منفى و غيرقابل تحمل و

\footnotetext{
${ }^{10}$-Gonzalez

${ }^{11}$ - Yu \&Lee

12 - subjective indicators

13 - objective indicators

14- Karat zias, Power, Fleming, Lennan\& Swanson

15 -Vaez\&Laflamme

16 - White\&Kern

17 - Adler

18 - Ahern

19 - Sieberer-Nagler

${ }^{20}$-Joshanloo \& Jarden

21- Eryilmaz

22. Shoshani\&Slone

${ }^{23}$ - positiveeducation
}

در سالهاى اخير بهزيستى به عنوان يكى از مؤلفه هاى اساسى كيفيت زندكى در كانون توجه روانشناسى مثبت كرا قرارگرفته است (لينلى، مالتبى، وود، آزبورن و و هارلينگ روانشناسى از دو ديد گاه هميوش و نسبتاً متمايز، (لذتى و سعادتى بَ كه داراى ريشه هاى فلسفى متفاوت هستند،

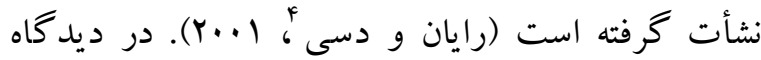
لذتى، بهزيستى از شاد كامى يا لذت تشكيل شده است و بر توازن بين عاطفه مثبت و منفى متمركز است؛ اما ديدگاه سعادتى با تلاش براى تحقق تو انايى انسان، درك نيروى الهام بخش ه فرد يا ماهيت حقيقى فرد مشخص شده است (ريف ؛? 1919). تحقيقات انجام شده توسط طرفداران سنت لذتى بهزيستى موجب ظهور مفهوم

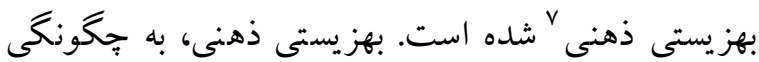
ارزيابى افراد از زندگى خود اطلاق مى گردد (دينر ^و

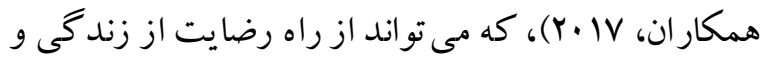
ارزش يابىهاى مبتنى بر احساس، خلق و هيجان حاصل

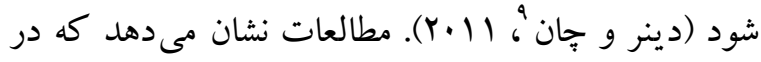

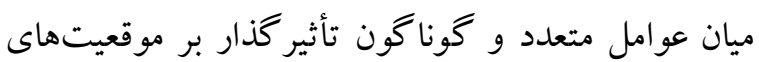
تحصيلى يادگيرندگان، بهزيستى ذهنى نقش برجسته و بلكه، مهم ترى را ايفا مىنمايد. لذا، شناخت و تحليل مناسب مؤلفههاى هيجانى و شناختى بهزيستى فراكيران و توجه به ارزشهاى فردى و اجتماعى دانش آموزان در تبين اثربخشى موقعيتهاى تحصيلى، از نقش

\footnotetext{
${ }^{1}$-Linley, Maltby, Wood,Osborne\& Harling

2- King

${ }^{3}$-hedonic\&eudaimonic

4- Ryan \&Deci

5 - daimon

${ }^{6}$ - Ryff

7 -subjective well-being

${ }^{8}$-Deiner

${ }^{9}$-Chan
} 
شناخت جنبهاى مثبت ديخران را كسب كنند. آنها از اين طريق ياد مى گيرند تا زندكى خود را شخصاً شكل داده و موضعى فعال در برابر رويدادها اتخاذ كنند و بهجاى جستوجو در ضعفها و نقصهاى خود بر نقاط قوت و توانيىهايشان تمركز كنند (اهرن، IV)

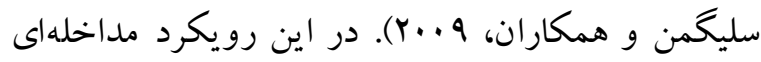
دانش آموزان مى آموزند كه به جاى سرزنش خود، تصور مثبتى از خود داشته باشند، كذشته را با رضايتمندى و وله خشنودى به خاطر آورند و به آينده اميدوار باشند، جالشها را به فرصت تبديل كرده و براى مقابله با افكار منفى و سبس بذيرفتن افكار مثبت به جاى آنها و نيز مؤثرتر كنار آمدن با مشكلات از راهبردهاى مقابلهاى

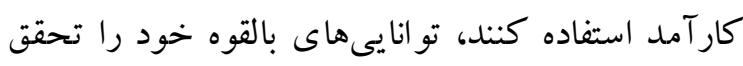
بخشند، از احساسات خودآكاه شوند و هيجانات و عواطف خود را كنترل كنند (آلن، كرن، ويلا-

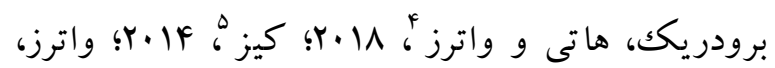

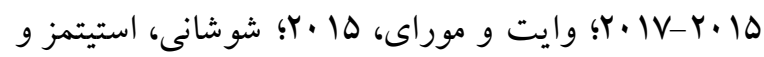

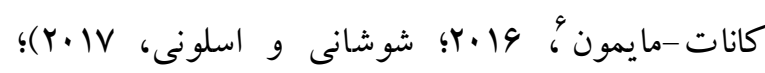
بنابراين، آموزش مثبت براى بهبود ارتباط مثبت دانش

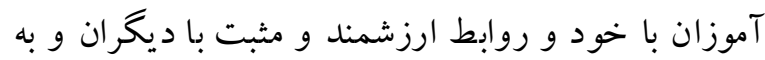
طور كلى ايجاد تعامل مثبت و ايجاد شبكههاى ارتباطى با ديخران، مثبت انديشى و وبرهيز از افكار منفى بسيار سودمند و مفيد به نظر مىرسد (فينكل، سيميسون و و

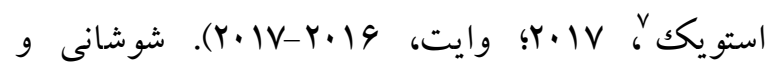
استونى (Y IV) در بررسى "آموزش مثبت براى كود كان: اثر بخشى مداخله آموزش مثبت بر بهزيستى ذهنى و و رفتارهاى يادگيرى كود كان بيشدبستانى "دريافتند كه

${ }^{4}$ - Allen, Kern, Vella-Brodrick\&Hattie

5 - Keyes

${ }^{6}$ - Steinmetz \& Kanat-Maymon

7. Finkel, Simpson \&East wick
تبديل آنها به عواطف مثبت از طريق مهارتآموزى، تمرين، بهينهسازى مطلوب و مورد بحث قرار دادن صحت افكار بدبينانه است (وايت و كرن، \|+r). در طول دو دهه كذشته آموزش مثبت بهعنوان هسته اصلى و

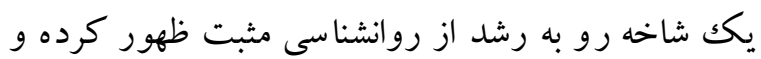
مورد استقبال بزوهشخران قرار گرفته است (سليخمن،

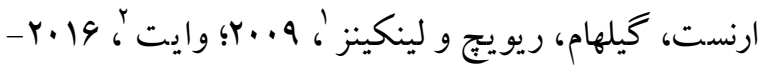

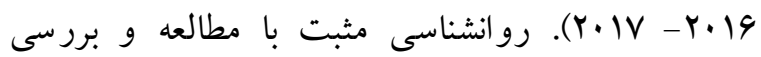
هيجانات و ويزگى هاى مثبت شخصيتى و جنبه هاى خوش بينانه ترى همجون سلامت روانى و بهزيستى مىبردازد و تمركز آن بر اين است كه زندكى انسان

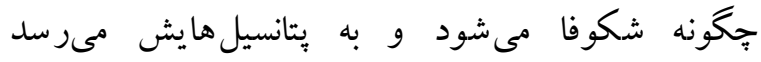

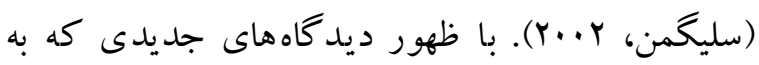
جاى درمان مشكلات روانى بر بيشخيرى از آنها تأكيد

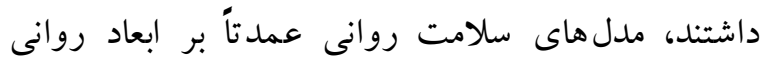
مثبت مانند تو انايىهاى انسان، رشد شخصى، بهزيستى و ارتقاى خوب بودن متمر كز شدند. در واقع صاحبنظران روانشناسى مثبت معتقدند كه بايد تلاش شود تا شرايط اجتماعى پشت پِده مشكلات روانى تصحيح شوند و به افرادى كه در معرض خطر ابتلا به مشكلات هيجانى

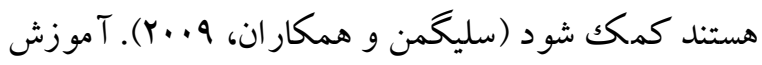
مثبت به عنوان قلب روانشناسى مثبت بر نقاط قوت،

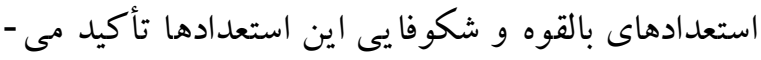
كند و تلاش دارد تا شناخت بيشترى از عواملى كه به دانش آموزان كمكك مى كند به صورت فردى و يا جمدىى

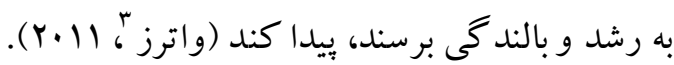
در آموزش مثبت، دانشآموزان تشويق مىشوند تا تجربهاى مثبت و خوب خود را بازشناسى و توانايى

\footnotetext{
1. Seligman, Ernst, Gillham, Reivich\&Linkins

2. White

3 - Waters
} 
شهرستان مرودشت تشكيل مىدادند كه از ميان آنها

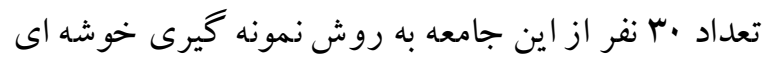
به عنوان نمونه انتخاب و در دو گرووه ها نفرى (كروه آزمايش و گروه كنترل) به صورت تصادفى جايخزين

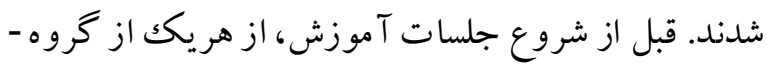

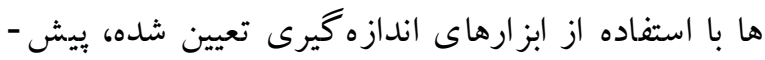

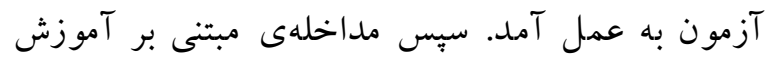

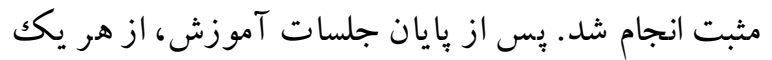

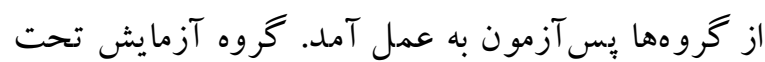
تأثير مداخلهى مبتنى بر آموزش مثبت طى ·ل جلسه يك ساعتى قرار گرفتند و گرووه كنترل آموزشهاى عادى كلاس خود را دريافت كردند. ملاكك هاى ورود به مطالعه شامل اشتغال به تحصيل در سال تحصيلى 99-9V، تكميل فرم شركت در تحقيق و جنسيت يسر بود. عدم تمايل به حضور در جلسات مداخله، غيبت بيش از دو جلسه، وجود بيمارىهاى طبى حاد و نيز بيمارىهاى روانيزشكى عمده با تشخيص متخصص ملاككهاى خروج از مطالعه بودند.

ابزار بزنامه عاطفه مثبت و منفى: به منظور بررسى بُعد عاطفى بهزيستى ذهنى، بر اساس برنامه عاطفه مثبت و منفى' (واتسون و همكاران، 1911)، از بيست صفت خلقى استفاده شد. ماده هاى برنامه عاطفه مثبت و منفى هيجانات و احساسات مختلفى را توصيف مى كنند و هر كدام به يكك مقياس عاطفه مثبت و يا يكك مقياس عاطفه منفى كروهبندى مىشوند. شركت كنندگان تمام مادهها را بر روى يكك مقياس ينجدرجهاى از نوع ليكرت باسخ مى

\footnotetext{
${ }^{1}$ - Positive and Negative Affect Schedule (PANAS)
}

آموزش مثبت باعث افزايش معنادار بهزيستى ذهنى و رفتارهاى يادگيرى مثبت گروه آزمايش در مقايسه با كروه كنترل گرديد. همجنين نتايج يافتهاى تحقيق

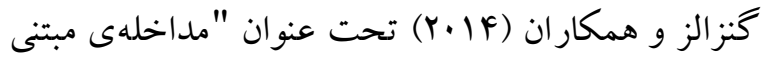
بر اثربخشى آموزش مثبت بر بهزيستى و نشاط دانش آموزان مكزيكى" نشان داد اين مداخله در ارتقاء بهزيستى و نشاط دانشآموزان در هر دو مرحلهى يس آزمون و ييخيرى مؤثر بوده است. اهرن (Y (Y) در بررسى"تعيين اثر برنامهى آموزش مثبت بر بهزيستى

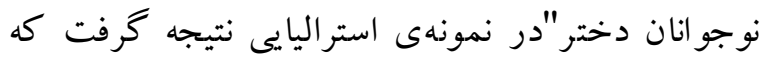
بين كروههاى آزمايش و كنترل يُوهش از نظر بهزيستى تفاوت معنادارى وجود دارد و اين برنامه توانست به صورت موفقيت آميزى مو جب افزايش تغييرات بلند مدت و كوتاه مدت بهزيستى دختران دانش آموز گروه آزمايش در مقايسه با خروه كنترل شود.

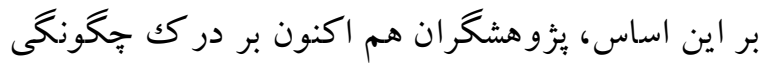

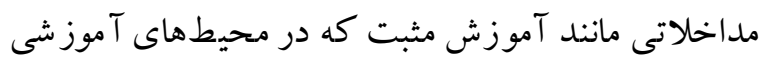
طبيعى به وسيله متخصصين آموزشى، قابل اجرا باشند، تمر كز دارند. به رغم مطالعات انجام شده در زمينهى تأثير مداخلهى آموزش مثبت بر بهزيستى ذهنى دانش آموزان در خارج از كشور، كمترمطالعهاى در اين زمينه در مدارس ابتدائى كشور ما مشاهده گرديد؛ بنابراين، مطالعه حاضر با هدف تعيين اثربخشى مداخلهى مبتنى بر آموزش مثبت بر بهزيستى ذهنى د انش آموز ان ابتدائى انجام شد. اين يزوهش از نظر هدف از نوع تحقيقات كاربردى است و از لحاظ طرح مطالعه، نيمه آزمايشى است كه در آن از كروه كنترل و نيز گمارش تصادفى استفاده شد. جامعه آمارى بُزوهش را كليه دانش آموزان بِيهى ششم ابتدائى 
دخترها و يُسرها به ترتيب YA/ · و • A/ محاسبه شدند. همجنين، بِيايى مقياس با استفاده از روش تنصيف براى كل مقياس |N/ • و براى بسرها و دخترها به ترتيب 191/.

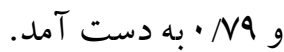
شيوه مداخله: برنامه مداخله آموزش مثبت كه در اين

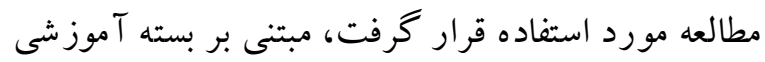

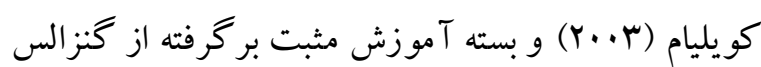

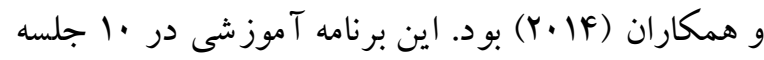
4 دقيقهاى و هر هفته يكك يا دو جلسه در محل تحصيل دانش آموزان آموزش داده شد. جلسات برنامه مداخلهى آموزش مثبت به صورت زير بر گزار شد.
دهند. در اين طيف عدد ا نشان دهنده (اعدم تجربه هيجان) و عدد ه بيانگر ("تجربه بسيار زياد هيجان) است. براى هر آزمودنى نمره كل عاطفه مثبت از طريق جمع نمرههاى شر كت كننده در هر يكك از ده صفت توصيفكر هيجانات مثبت و نمره كل عاطفه منفى، از طريق جمع نمرههاى شركت كننده در هر يكك از ده صفت توصيفگ هيجانات منفى محاسبه مىشود. ئزوهش بخشى يور رودسرى (צ (1))، همسو با نتايج مطالعه واتسون و

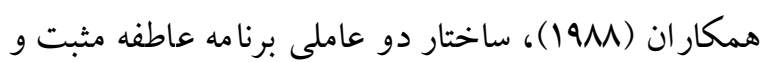
منفى را در بين دانشجويان ايرانى، مورد تأييد قرار داد.

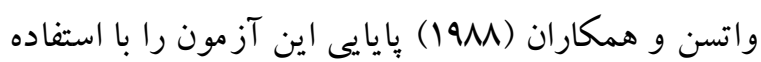
از روش باز آزمايى، با فاصله ^ هفته، براى خرده مقياس

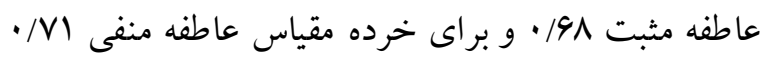

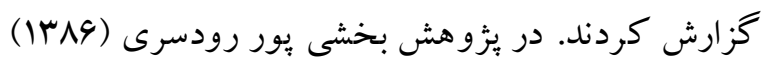

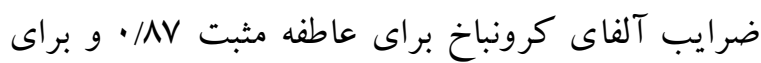
عاطفه منفى ل/ • •ز ارش شده است. مقياس رضايت از زندكى: دينر و همكار ان ( ه1911) به منظور اندازه گيرى بُعد شناختى بهز يستى ذهنى افراد،

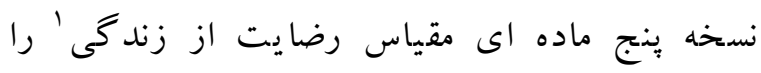
توسعه دادند. در اين مقياس، شركت كنندگان به هر ماده بر روى يكك طيف ينج درجه ایى از نوع ليكرت (از ا كاملاً مخالف تا ه كاملاً موافق) بِاسخ مى بـدهند. يافته هاى مطالعات دينر و همكاران و وييوت'، دينر،

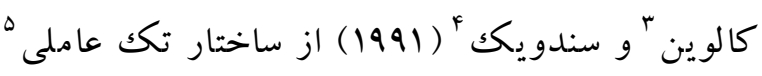
اين مقياس حمايت كرد. در بثزوهش تقوائىنيا (MMM )، ضرايب بايايى مقياس رضايت از زندگى با با استفاده از

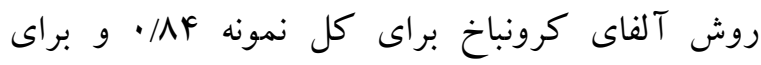

\footnotetext{
1- Satisfaction With Life Scale (SWLS)

2- Pavot

3- Colvin

${ }^{4}$ - Sandvik

5- unidimentional structure
} 
محتواى مداخله آموزش مثبت به تفكيك جلسات

\begin{tabular}{|c|c|}
\hline محتوا & جلسه \\
\hline ايجاد رابطه اوليه، آشنا كردن اعضاى گروه با يكديخر، تشريح فرايند انجام كار، آشنايى با مفهوم آموزش مثبت، انتخاب & جلسه اول \\
\hline مرور تكليف جلسه قبل، آموزش مثبت و تكنيك هاى آن، تمركز بر فر آيند تنفس در هر مرحله از تمرينات به منظور ارتقاء & 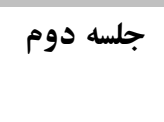 \\
\hline 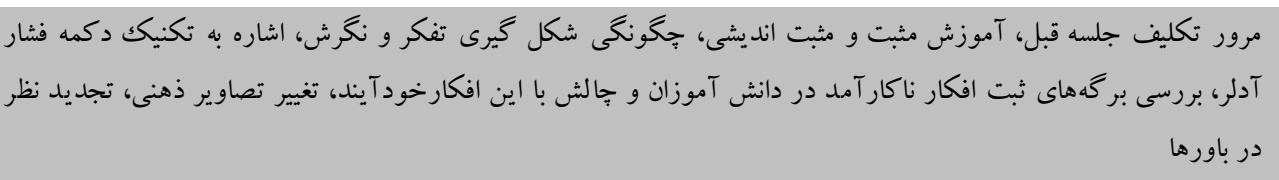 & 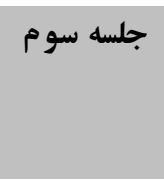 \\
\hline 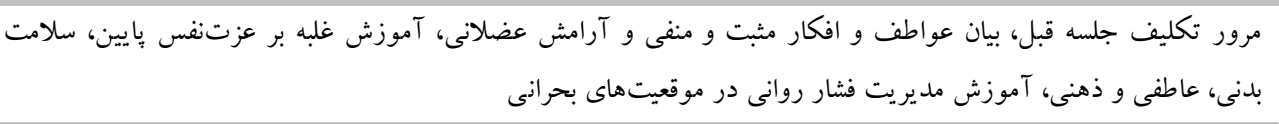 & جلسه جهارم \\
\hline مرور تكليف جلسه قبل، توسعه آكاهى نسبت به باورهاى زيربنايى، تقويت خود گويى هاى مثبت، استفاده از فنون رفتارى & جلسه ينجم \\
\hline تمرور تكليف جلسه قبل، تمرين تمركز ذهن -بدن و كاربردهاى آن. شيوه استفاده از تكنيك تمركز ذهن ذبدن و امتحان آن، & جلسه ششم \\
\hline مرور تكليف جلسه قبل، كنارآمدن و ساز گارى با مشكلات، واردكردن خنده به زندگى، ايجاد اعتمادبهنفس، تعريف كردن & جلسه هفته \\
\hline مرور تكليف جلسه قبل، تمرين مثبت زندگى كردن از طريق ايجاد رابطه مثبت، آكاه شدن از نقاط مثبت خود و ديخران، & جلسه هشتم \\
\hline مرور تكليف جلسه قبل، راه هاى رسيدن به احساس مثبت مانند كاشتن يكك دانه و يا انجام كارى ارزشمند، بيان ييام هاى & جلسه نهم \\
\hline مرور جلسات قبل و گرفتن بازخورد از آزمودنىها، تمرين اعتماد به توانايىهاى خود، تشكر از آزمودنىها، كُفتن پس آزمون & جلسه دهم \\
\hline
\end{tabular}

به منظور اثربخشى مداخلهى مبتنى بر آموزش مثبت بر بهزيستى ذهنى دانش آموزان از تحليل كوواريانس استفاده شد. در خارجوب شاخص دهاى دانش توصيفى، نتايج

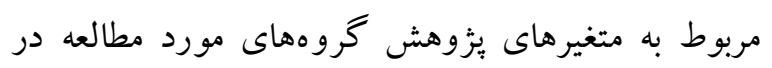

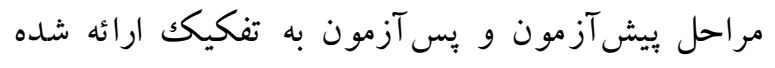

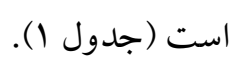

دادههاى يزوهش در سطح توصيفى با ميانگين و انحراف

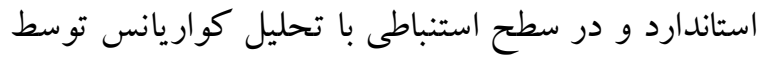

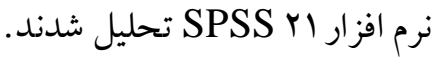

يافته ها

جدول ا ميانكين و انحر اف معيار خرده مقياس هاى بهزيستى ذهنى در كروه آزمايش و كنترل در مراحل بيشآزمون و يِّآزمون

\begin{tabular}{|c|c|c|c|c|}
\hline \multicolumn{2}{|c|}{ كروه كنترل } & \multicolumn{2}{|c|}{ كروه آزمايش } & \multirow[t]{3}{*}{ متغير ها } \\
\hline ي بس آزمون & 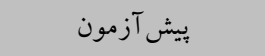 & 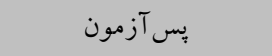 & يِي آزمون & \\
\hline ميانخين (انحراف معيار) & ميانگين (انحراف معيار) & ميانخين (انحراف معيار) & ميانكين (انحراف معيار) & \\
\hline$(9 / \Delta)(r+1)$ & $(\varphi / \Delta V) r T / r \Delta$ & $(q / F \wedge) F \cdot / V$ & $(g / r F) H / 1$ & عاطفه مثبت \\
\hline
\end{tabular}




\section{政}

عاطفه منفى (pV) • /

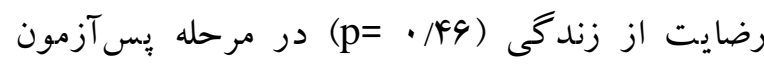
حاكى از نرمال بودن توزيع نمرات بود. يافتهاى مربوط به آزمون لوين براى عاطفه منفى (F= / (F)، عاطفه

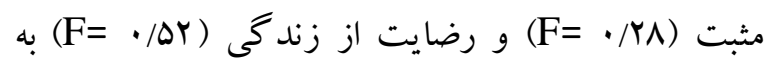
ترتيب با سطح معنىدارى (p= = (p= • در مرحله يس آزمون به دست آمد. اين يافته نشان مىدهد كه فرض برابرى واريانسهاى دو گروه در مرحله يس آزمون برقرار است. همجيخين نتايج بيش فرض

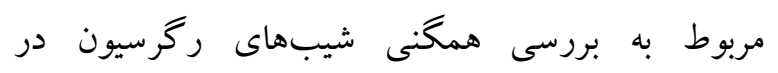
متغيرهاى يزٔوهش در جدول Y كز ارش شده است.
طبق جدول ا، ميانخين نمرات عاطفهى منفى در پِّ - آرمات

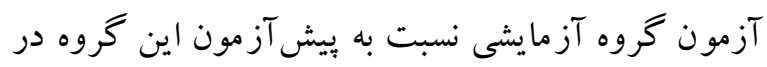
مقايسه با گروه كنترل بايين تر است. همجنين ميانكين

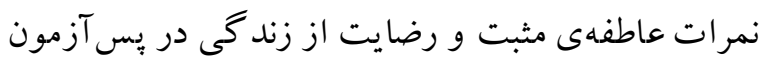

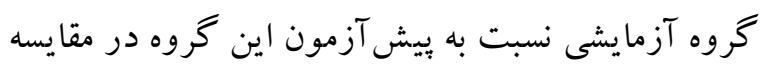

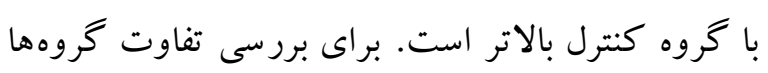

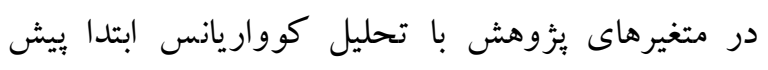

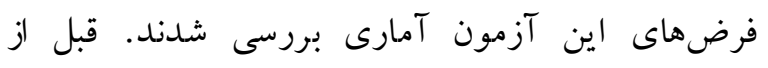

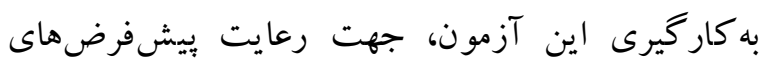

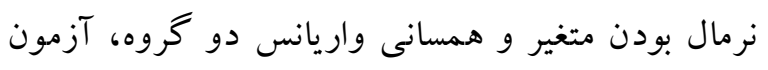

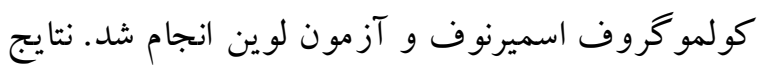

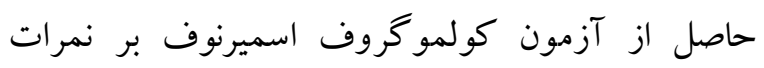

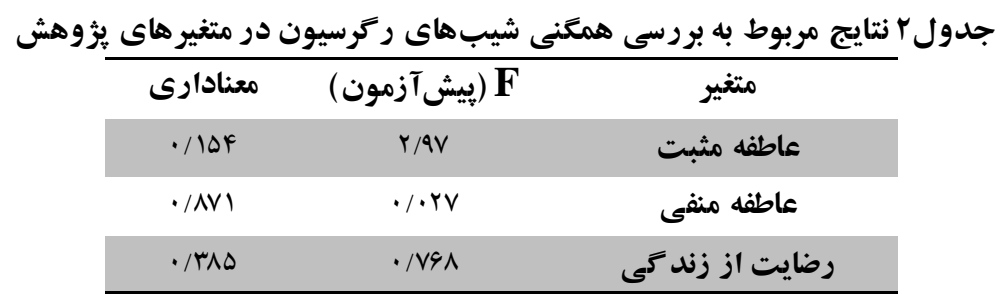

رعايت شده است. بر اين اساس براى اطمينان از وجود تفاوت معنى دار بين دو كروه كنترل و آزمايش و اندازه ـ كيرى تأثير مداخله، تحليل كواريانس جند متغيرى اجرا Fرديد. نتايج آزمون لامبداى ويلكز نشان داد كه مقدار

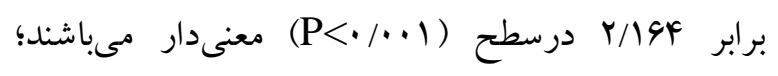
بنابراين مى توان بيان داشت كه حداقل در يكى از خرده مقياس هاى عاطفه مثبت، عاطفه منفى و رضايت از زندگى در بيش آزمون و بس آزمون دو گروه آزمايش و كنترل تفاوت معنىدارى وجود دارد. ضريب اندازه اثر اين
نتايج مربوط به بررسى همكنى شيبهاى رگرسيون درمتغيرهاى يزوهش جدول (Y) نشان مىدهد مفروضه همخنى شيبهاى ركرسيون رعايت شده است. به طور كلى با تو جه به بررسى هاى انجام شده در خصوص نرمال بودن داده ها با آزمون كولمو گروف، عدم معنادارى خطاى همسانى واريانس ها توسط آزمون لوين و برر سى

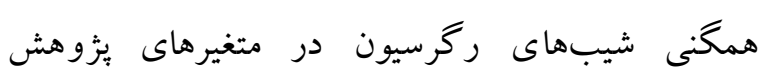
مىتوان بيان نمود كه مفروضات اساسى روش آمارى يارامتريكك و تحليل كوواريانس جند متغيره (مانكوا) 
آنكوا در متن مانكوا انجام گرفت كه نتايج حاصل از آن

$$
\text { درجدول شماره س درج شده است. }
$$

آموزش بر روى بهزيستى ذهنى 191/ بود كه نشان مى دهد 91 درصد تفاوت دو گرووه مربوط به مد مداخله آزمايشى است. جهت بيى بردن به اين تفاوت تحليل

\begin{tabular}{|c|c|c|c|c|c|c|c|}
\hline توان آمارى & ضريب اتا & معنادارى & $\mathbf{F}$ & مجذوراتكين & درجه آزادى & مجذوروات & متغير ها \\
\hline - Na & $\cdot / \Delta \Delta$ & $\cdot / \cdot r$ & $9 Y / .0$ & $\mid r \Delta / r \Delta$ & 1 & ITO/RD & عاطفه مثبت \\
\hline .191 & $\cdot|4|$ & $\cdot / \cdot r$ & $r \Delta / 9 \Delta$ & $10 / 99$ & 1 & $1 \otimes / 99$ & عاطفه منفى \\
\hline .199 & $\cdot / r r$ &.$/ . .4$ & N/Tr & $99 / 1 \pi$ & 1 & $99 / 1 \pi$ & رضايت از زند \\
\hline
\end{tabular}

كنزالز و همكاران (Y.|Y) شوشانى و همكاران (Y.19) شوشانى و استونى (Y.IV) اهرن (Y.IV) همسو است. يافتهاى فرا تحليل وايت و موراى (ها. (Y) كه به بررسى نتايج •10 مقاله، مجله و بزٔوهش در زمينه تأثير مداخله آموزش مثبت در افزايش بهزيستى در دانش آموزان برداخته است، نشان مىدهد مداخلههاى مثبت نخر موجب افزايش بهزيستى در د انش آموزان و كاهش مشكلات روانشناختى آنها مىشود. يافتهاى فرا تحليل

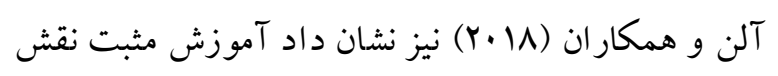
قابلتوجهى در افزايش بهزيستى دانش آموزان دارد. همسو با اين يافتها و در تبيين نتايج بهدست آمده در اين يُوهش مى توان جنين كفت كه آموزش مثبت به دليل

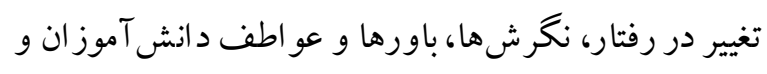
برخوردار كردن آنها از ويز گیىهايى مانند فعال و و باورها يرانرزى بودن، تمايل به برقرارى ارتباط با ديخران، مثبت نخرى و داشتن نخرش و تصور مثبتى از خود و افراد ديخر بودري و كنترل هيجانات به توانمندسازى آنان كمكك مى كند. نتيجه جنين تو انمندسازىهايى تقويت هيجانهاى مثبت و كسب موفقيت هاى بيشتر در زندگى است. مى توان كفت تونت
مندرجات جدول r نشان مىدهد در مجموع تفاوت معنادارى بين خرده مقياس هاى عاطفه مثبت، عاطفه منفى و

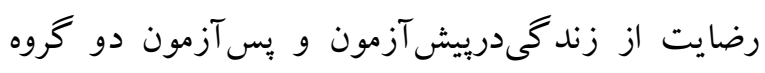
آزمايش و كنترل وجود دارد. هدف بُزوهش حاضر، بررسى اثربخشى مداخلهى متمركز بر آموزش مثبت بر ارتقاء بهز يستى ذهنى دانش آموزان بود. نتايج تحليل كواريانس جند متغيرى نشان داد كه مداخله ى متمركز بر آموزش مثبت بر ارتقاء بهزيستى ذهنى

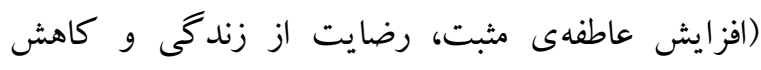
عاطفهى منفى) در مراحل يس آزمون تأثير معنىدارى دارد. يافتهاى توصيفى مربو ط به عاطفهى مثبت و رضايت از زندگى در مراحل بـ آزمون در مقايسه با مرحله بيش آزمون نيز حاكى از تأثير مداخلهى متمركز بر آموزش مثبت در افزايش عاطفهى مثبت و رضايت از زندكى و كاهش عاطفهى منفى دانش آموزان بود. بر اين اساس، نتايج بزوهش حاضر از اين نظر كه مداخلهى آموزش مثبت بر بهزيستى ذهنى دانشآموزان تأثير مى گذارد با

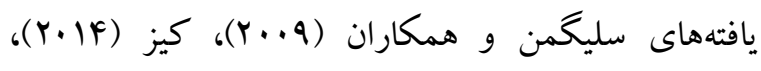


به سلامت رفتارى و ارتباطى خود احساس مسئوليت بيشترى مى كنند. همين امر موجب مى شود تمايل كمترى به گروههاى داراى رفتارهاى برخطر داشته باشند. هم

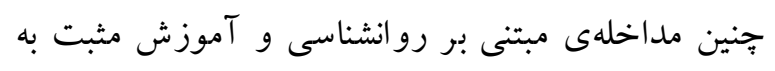
ايجاد و تقويت توانمندى، تسلط محيطى، خودمختارى،

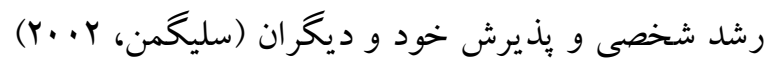
در دانش آموزان منجر مى شود و به آنها كمكك مى كند تا كنترل بالاترى بر تكانه هاى خود داشته باشند كه اين امر نيز آنها را در مقابل آسيبهاى اجتماعى حفظ مى كند و موجب مىشود كه موفقيتهاى اجتماعى بيشترى كسب كنند و سلامت روان بالاترى داشته باشند.

\section{نتيجه كيرى}

در مجموع، مداخلهى متمركز بر يثزوهش حاضر يعنى

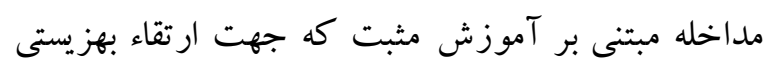
ذهنى دانشآموزان استفاده شد با تمايز كذاشتن ميان عو اطف مثبت و منفى و همج جنين ساز گار يا ناساز گار بودن آنها، دانش آموزان را به بازانديشى دوباره نسبت به هيه افكار خود آكاه مىنمايد و شدت عواطف منفى را كه دربردارنده تحريف افكار منفى و يا سرزنش نمودن خود است را كاهش مىدهد و از طريق كنترل نقاط ضعف و اصلاح جنبههاى تنشزاى زندگى باعث مى شود تا آنها ديد مثبتى به زندگى داشته باشند. صرفنظر از اين نتيجه -

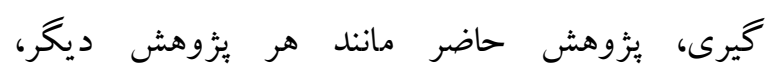
محدوديت هايى داشته است. در اين بزٔوهش، براى اندازه گيرى متغير وابسته از ابزار خود سنجى به جاى رفتار واقعى استفاده شد و مطالعه يُيخيرى انجام نخرفت. محدوديت ديخر، آن بود كه بررسى روش مداخلهاى

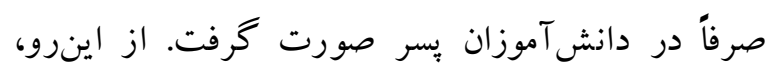

كه آموزش مثبت باعث فعال شدن عواطف و هيجانات

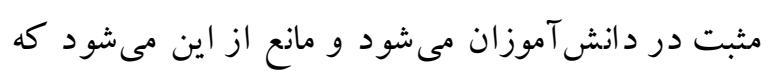
عواطف منفى كه نقشى اساسى در كاهش بهزيستى ذهنى آنها دارد جايخزين عواطف مثبت شوند (سليخمن و واطفي

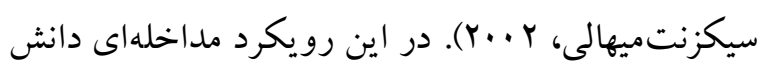
آموزان مى آموزند كه به جاى سرزنش خود، تصور مثبتى از خود داشته باشند، كذشته را با رضايتمندى و خشنودى امورى به خاطر آورند و به آينده اميدوار باشند (وايت و موراى، ها ·r)، جالشالشها را به فرصت تبديل كرده و براى مقابله با افكار منفى و سِّ بذيرفتن افكار مثبت به جاى آنها و نيز مؤثرتر كنار آمدن با مشكلات از ر اهبردهاى مقابلهاى

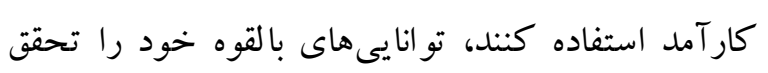
بخشند، از احساسات خود آكاه شوند و هيجانات و وان

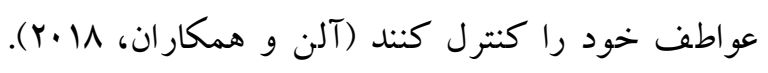
علاوه بر اين، آموزش مثبت منجر به ايجاد فعاليتهايى مى -

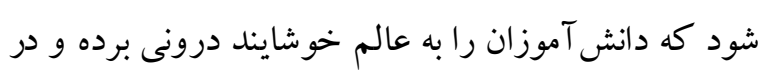
به دست آوردن حس شور و نشاط، معنايابى در زندگى، رضايت از زندكى، افزايش اعتماد به نفس، به دست آوردن

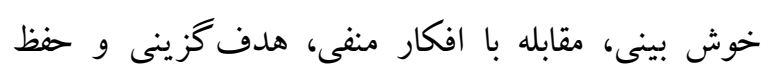
انكيزش به آنها كمكك مى كند و به تبع آن بر بهزيستى و

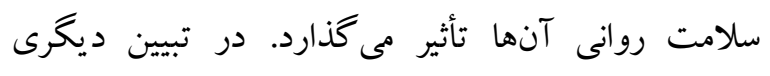
مى توان به نظر يههاى شناختى استناد كرد كه معتقدند افراد مثبت انديش رويدادهاى مطلوب بيشترى را تجربه مى كنند و رويدادهاى خنثى را بهصورت مثبت در نظر

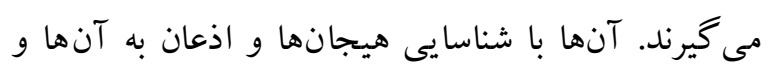

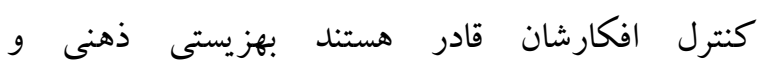

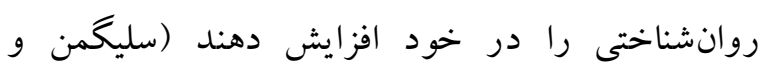

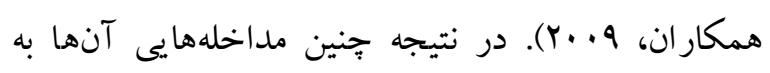
سمت جنبههاى مثبت اجتماعى متمايل مىشوند و نسبت 
Adler, A. (2017). Positive education: Educating for academic success and for a fulfilling life. Papeles Del Psicólogo, 38(1), 50-57.

Allen, K. A., \& Kem, M. L. (2017). School belonging in adolescents: Theory, research, and practice. Singapore: Springer.

Allen, K., Kem, M. L., Vella-Brodrick, D., Hattie, J., \& Waters, L (2018). What schools need to knowabout fostering school belonging: A meta-analysis. Educational Psychology Review, 30(1), 1-34.

Bakhshipour Roudsari, A. (2006). A confirmatory factor analysis of the Positive Affect and Negative Affect Scales ( PANAS). Joumal of Psychology. 9(36):351-65. (Persian).

Diener, E., \& Chan, M. Y. (2011). Happy people live longer: Subjective well-being contributes to health and longevity. Applied Psychology: Health and Well-Being 3(1), 1-43.

Diener, E., Emmons, R., Larsen, R. J., \& Griffin, S. (1985). The Satisfaction with Life Scale. Joumal of Personality Assessment, 49, 71-75.

Diener, E., Heintzelman, S. J., Kushlev, K., Tay, L. Wirtz, D., Lutes, L. D., \&Oishi, S. (2017). Findings all psychologists should know from the new science on subjective well-being. Canadian

Psychology/psychologiecanadienne, 58, 87.

Eryllmaz, A. (2015). Positive psychology in the class:

The effectiveness of a teaching method based on subjective well-being and engagement increasing activities.Intemational Journal of Instruction, 8(2),17-32.

Finkel, E. J., Simpson, J. A., \&Eastwick, P. W. (2017). The psychology of close relationships: Fourteen core principles. Annual Review of Psychology, 68, 383-411.

Gonzalez, T. R., Ehrenzweig, Y., Gracida, D. S., Hemandez, C. B., Mora, G. L., Martinez, A. G., \&Laralde, C. (2014). Promotion of individual happiness and wellbeing of students by a positive education intervention. Joumal of Behavior, Health \& Social Issues , $5,2,79-102$.

$$
\begin{aligned}
& \text { تعميم نتايج به دانش آموزان دختر به سادگى امكانيذير } \\
& \text { نخواهد بود. بيشنهاد مى شود براى سنجش و ارزيابى } \\
& \text { بهزيستى ذهنى دانش آموزان قبل و بعد از مداخله علاوه } \\
& \text { بر زبرسشنامهاى خودسنجى از مصاحبه و اندازههاى } \\
& \text { حاصل از مشاهده در موقعيتهاى طبيعى استفاده شود. در } \\
& \text { يزّوهشهاى بعدى با كنجاندن مطالعه بِيخيرى، مى توان } \\
& \text { تأثير آموزش مثبت را در دانش آموزان ارزيابى كرد. } \\
& \text { همجنين بيشنهاد مى شود بزوهشى مشابه اين بزوهش بر } \\
& \text { روى دانش آموزان دختر انجام شود تا بتوان اثربخشى اين } \\
& \text { روش مداخلهاى را با توجه به جنسيت نيز تعيين نمود. } \\
& \text { علاوه بر اين، از آنجا كه مداخلهى آموزش مثبت يك } \\
& \text { شيوه نوين در حوزهى آموزش و روانشناسى مثبت است، } \\
& \text { لذا بيشنهاد مىشود كه اين مداخله به صورت يكك برنامه } \\
& \text { منظم و مداوم در طول سال تحصيلى به دانش آموزان } \\
& \text { آموزش داده شود و به صورت يكك شيوهى معمول در } \\
& \text { آموزش مدارس كنجاند شود. }
\end{aligned}
$$

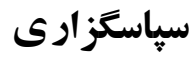

$$
\begin{aligned}
& \text { در پيايان از مديران و معلمان مدارسى كه با اينجانب }
\end{aligned}
$$

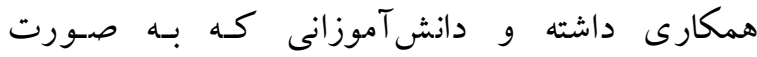

$$
\begin{aligned}
& \text { داوطلبانهه در اين بزوهش شركت كردند، صميمانه تشكر }
\end{aligned}
$$

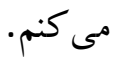

\section{Refrences}

Ahern, M. (2017) Exploring the impact of a positive education program on the wellbeing of adolescent girls. Professional Doctorate thesis, Queensland University of Technology. 
Joshanloo, M., \&Jarden, A. (2016). Individualismas the moderator of the relationship between hedonism and happiness: A study in 19 nations. Personality and Individual Differences, 94, 149-152.

Karatzias, A., Power, K. G., Feming J., Lennan, F., \& Swanson, V. (2002). The role of demographics, personality variables and school stress on predicting school satisfaction/dissatisfaction: Review of the literature and research findings. Educational Psychology, 22(1), 33-50.

Keyes, C. (2014). The nature and importance of positive mental health in America's adolescents. In M. J.Furlong, R. Gilman, \& S. Huebner (Eds.), Handbook of positive psychology in schools (pp. 9-23). Florence, Italy: Taylor \& Francis Group.

King, L. A. (2008) .Interventions for enhancing subjective well-being, In R. J. Larsen \& M. Eid (Eds.), The science of subjective well being(pp. 431- 448), New York, The Guilford Press.

Linley, A. P, Maltby, J. Wood, A. P., Osbome, G., \& Hurling R. (2009). Measuring happiness: The higher order factor structure of subjective and psychological well being measures.

Personality and Individual Differences, 47, 878-884.

Pavot, W., Diener, E., Colvin, C. R., \&Sandvik, E. (1991). Further validation of the Satisfaction with Life Scale: Evidence for the crossmethod convergence of well-being measures. Journal of Personality Assessment, 57, 149161.

Ryan, R. M., \&Deci, E. L. (2001). On happiness and human potentials: A review of research on hedonic and eudemonic well-being. Annual Review of Psychology, 52, 141-166.

Ryff, C. D. (1989). Happiness is everything or is it? Explorations on themeaning of psychological well-being.Journal of Personality and Social Psychology, 57(6), 1069-1081.

Seligman, M. E. P., \&Csikszentmihalyi, M. (2000). Positive psychology: An introduction. AmericanPsychologist, 55, 5-14.
Seligman, M.EP. (2002). Authentic happiness: using the newpositive psychology to realize your potential for lastingfulfillment. New York: FreePress

Seligman, M.E.P., Ernst, R.M., Gillham, J., Reivich K., \&Linkins,M. (2009). Positive education: Positive psychology andclassroom interventions. Oxford Review of Education, 35,293-311.

Shoshani, A., and Slone, M. (2013).Positive education for youngchildren: Effects of a positivepsychologyinterventionforpreschool children on subjectivewell being and leaming behaviors.Frontiers in Pscyhology,8(66), 1-11.

Shoshani, A., Steinmetz, S., and Kanat-Maymon, Y. (2016). Effects of theMaytiv positive psychology school program on early adolescents' well-being engagement, andachievement. J. Sch Psychol 57,73-92.

Sieberer-Nagler, K. (2016). Effective classroommanagement \& positive teaching.English Language Teaching, 9(1), 163-172.

Taghvaeinia, A. (2012). The causal relationship between perceived academic stress and subjective well-being, with mediating roles of perceived social support and academic selfefficacy beliefs among undergraduate students of Shahid Chamran Uneversity. Phd dissertation of Psychology. Uneversity of Shahid Chamran Ahwaz (Persian).

Phd dissertation of Clinical Psychology. University of Welfare and Rehabilitation Sciences Tehran. [Persian]

Vaez, M., \&Laflamme, L. (2008).Experienced stress, psychologicalsymptoms, self-rated health and academic achievement: A longitudinal study of Swedish university students.Social Behavior and Personality, 36, 183-196.

Waters, L. (2011). A review of school-based positive psychology interventions. The Australian Educationaland Developmental Psychologist, 28(2), 75-90.

Waters, L (2015). Why positive education? TLN Journal, 22(3), 16- 18.

Waters, L. (2017). Progressing positive education and creating visible wellbeing. In S. Donaldson \& 
M. Rao (Eds.). Scientific advances in positive psychology (pp. 229-256). Westport. Connecticut:Praeger.

Waters, L, \& White, M. (2015). Case study of a school wellbeing initiative: Using appreciative inquiry to support positive change. Joumal of Wellbeing, 5(1), 19-32.

Watson, D., Clark, L. A., \&Tellegen, A. (1988). Development and validation of brief measures of positive and negative affect: The PANAS scales. Joumal of Personality and Social Psychology, 54, 1063-1070.

White, M. \& Kem. M. L. (2017). Wellbeing: If you treasure it you will measure it. Independence Joumal ofthe Association of Heads of Independent Schools of Australia, 42(2), 5054.

White, M. A. (2016). Why won't it stick? Positive psychology and positive education. Psychology of Well-Being 6, 1-16.

White, M. (2017). Impact of activity:Future direction of positive education. In M. White, G. Slemp, \& S. Murray, Future directions in wellbeing: Education, organizations and policy (pp. 2733). Springer, the Netherlands.

White, M. A., \& Kern, M. L. (2018). Positive education: Learning and teaching for wellbeing and academic mastery. Intemational Joumal ofwellbeing, 8(1), 1-17.

White, M. A., \& Waters, L. E. (2015). A case study of 'The Good School:' Examples of the use of Peterson's strengths-based approach with students. The Journal of Positive Psychology, 10,69-76.

White, M., \& Murray, A. S. (2015). Well-being as freedom: Future directions in well-being. In M. White \& S. Murray (Eds.), Evidence-based approaches in positive education: Implementing a strategic frameworkforwellbeing in schools (pp. 167-175). Dordrecht, the Netherlands:Springer.

Yu, G., \& Lee, D. J. (2008). A model of quality of college life (QCL) of students in Korea. Social Indicators Research, 87(2), 269-286. 